CLINICAL STUDY

\title{
Body composition during GH replacement in adults - methodological variations with respect to gender
}

\author{
Josef Koranyi $^{1}$, Ingvar Bosaeus ${ }^{2}$, Magne Alpsten ${ }^{3}$, Bengt-Åke Bengtsson ${ }^{1}$ and Gudmundur Johannsson ${ }^{1}$ \\ ${ }^{1}$ Research Centre for Endocrinology and Metabolism, ${ }^{2}$ Department of Clinical Nutrition and ${ }^{3}$ Department of Radiation Physics, Sahlgrenska University \\ Hospital, SE-413 45 Göteborg, Sweden
}

(Correspondence should be addressed to J Koranyi; Email: josef.koranyi@medic.gu.se)

\begin{abstract}
Objective: Men with growth hormone deficiency (GHD) may be more sensitive to GH treatment than women in terms of changes in body composition. We have studied whether age, body-mass index (BMI) and the different types of methodology used to assess body composition may explain these differences.

Design: Forty-four men and forty-four women with GHD, closely matched for age and BMI, were studied before and after 6 months of GH replacement. The dose of GH was individually adjusted. Body composition was assessed by measurements of potassium-40, total body nitrogen (TBN), tritiated water dilution, dual-energy X-ray absorptiometry (DXA) and bioelectrical impedance analysis (BIA). Four- and five-compartment models for body composition were also calculated.

Results: The total daily dose of GH was similar in men and women at 6 months. Serum insulin-like growth factor-I (IGF-I) was higher in men than women at baseline and after 6 months of treatment $(P=0.01$, paired $t$-test). The increment was, however, similar. In women, GH treatment reduced body weight and increased TBN. In both men and women, total body water and body cell mass increased, while total body fat (BF) mass decreased. At baseline, mean total BF varied considerably depending on the methodology used, with the highest value obtained from DXA. The changes in BF were, however, less dependent on the methodology, but DXA and BIA demonstrated the largest inconsistency between men and women.

Conclusions: These results suggest that gender differences in body composition in response to GH treatment are small, if adjustments are made for baseline factors such as age, BMI and dose of GH. Different methods of body composition measurements produce different results, but changes in response to $\mathrm{GH}$ administration are less inconsistent.
\end{abstract}

European Journal of Endocrinology 154 545-553

\section{Introduction}

Men with growth hormone (GH) deficiency (GHD) may be more responsive to $\mathrm{GH}$ replacement therapy than women in terms of increase in serum insulin-like growth factor-I (IGF-I), anabolic action on lean tissue and bone mass, and reduction in total body fat mass (BF) $(1-5)$. Gender or sex steroid replacement therapy could explain some of these differences, as sex steroids interact differently with GH. Oral oestrogen administration reduces serum IGF-I levels (6), probably through direct hepatic action of oestrogen. Oral oestrogen may in a similar manner also increase the amount of $\mathrm{BF}$ and reduce lean tissue mass in postmenopausal women (7). Oestrogen has also in vitro been shown to attenuate GH receptor signalling (8). Testosterone, on the other hand, induces protein anabolism and reduces central adiposity when administered as a replacement therapy in hypogonadal men (9), actions similar to those obtained by GH. Moreover, data also suggest that testosterone and GH may act synergistically on protein anabolism (10).

Young and middle-aged, healthy women have markedly higher $\mathrm{GH}$ secretion than age-matched men $(11,12)$. Most previous studies comparing the responsiveness of men and women with GHD have administered $\mathrm{GH}$ per $\mathrm{kg}$ body weight, resulting in men receiving a higher total daily dose of $\mathrm{GH}$ than women $(3,13,14)$, and this possibly explains some of the differences observed. The large differences in responsiveness to $\mathrm{GH}$ treatment may also be explained by age and adiposity (3) as well as the different methods used to assess body composition (15). These factors have not been considered in previous comparisons of the response to $\mathrm{GH}$ treatment in men and women. 
The primary aim of this study was to investigate the treatment response in women and men, in terms of body composition, when the GH replacement dose is individually adjusted $(16,17)$ and the men and women are closely matched in age and BMI. The secondary aim was to determine whether gender differences in response to $\mathrm{GH}$ replacement depend on the method used to assess body composition.

\section{Patients and methods}

\section{Patients}

One hundred consecutive hypopituitary adults (44 women and 56 men) with verified severe GHD, defined as $\mathrm{GH}$ response less than $3 \mu \mathrm{g} / \mathrm{l}$ during insulin-induced hypoglycaemia, were eligible for the study. The men and women were closely matched individually in terms of age and BMI. This procedure resulted in the selection of 44 men and 44 women. Twelve men were not included, as no match could be found.

Pituitary tumours were the most common cause of GHD (Table 1). In 37 men and 38 women, the onset of GHD took place in adult life. When required, patients received adequate and stable replacement therapy with glucocorticoids, L-thyroxine and sex steroids at least 6 months before the start of $\mathrm{GH}$ replacement (Table 1). The distribution of pituitary hormone deficiencies was similar among men and women except for hypogonadotrophic hypogonadism, which was more frequent among the women $(75 \%$ vs $93 \%, P=0.02)$. Twenty-two women received oral and ten women received transdermal oestrogen replacement therapy.

\section{Study protocol}

All patients received a low initial GH dose, independent of body weight (BW). After 1, 3 and 6 months of treatment,

Table 1 Diagnosis and degree of hypopituitarism in 44 men and 44 women with $\mathrm{GH}$ deficiency.

\begin{tabular}{lrcr}
\hline Atiology & Men & Women & Total \\
\hline Acromegaly & 2 & 3 & 5 \\
Cushing's disease & 1 & 5 & 6 \\
Non-functioning adenoma & 19 & 13 & 32 \\
Craniopharyngioma & 4 & 3 & 7 \\
Parasellar tumour & 3 & 3 & 6 \\
Prolactinoma & 5 & 4 & 9 \\
Other & 10 & 13 & 23 \\
Type of deficiency & & & \\
Isolated GHD & 6 & 3 & 9 \\
$\mathrm{~T}^{*}$ & 4 & 0 & 4 \\
$\mathrm{G}^{*}$ & 3 & 5 & 8 \\
A $+\mathrm{T}^{*}$ & 1 & 0 & 1 \\
T $+\mathrm{G}^{*}$ & 8 & 8 & 16 \\
$\mathrm{~A}+\mathrm{T}+\mathrm{G}^{*}$ & 22 & 28 & 50 \\
\hline
\end{tabular}

* Secondary thyroid $(T)$, gonadal $(G)$ or adrenal $(A)$ insufficiency. the dose was re-evaluated according to age- and sexadjusted reference values for serum IGF-I and clinical response, as previously described (16). The dose of GH was reduced by half in the event of side effects, a decision based solely on clinical criteria of GH excess, such as arthralgia and peripheral oedema.

At the start of the study; after 1 week; and after 1,3 and 6 months, side effects were recorded and serum IGF-I measurements were made. Physical and laboratory examinations, including measurements of body composition, were performed at baseline and at 6 months. Body weight was measured in the morning to the nearest $0.1 \mathrm{~kg}$ and body height was measured barefoot to the nearest $0.01 \mathrm{~m}$. The BMI was calculated as body weight in kilograms divided by height in metres squared.

\section{Biochemical assays}

Blood samples were drawn in the morning after overnight fast. The serum concentration of IGF-I was determined by hydrochloric acid-ethanol extraction RIA with authentic serum IGF-I for labelling (Nichols Institute Diagnostics, San Juan Capistrano, CA, USA). The interassay coefficient of variation (CV) was $2.5 \%$ and $4.2 \%$ at serum concentrations of 125 and $345 \mathrm{mg} / \mathrm{l}$ respectively. To compare individual serum IGF-I concentrations with normative values from the general population, a serum IGF-I S.D. score (SDS) was calculated as previously described (18).

\section{Body composition}

Total body potassium (TBK) was determined by counting the emission of $1.46 \mathrm{MeV}$ gamma radiation from the naturally occurring ${ }^{40} \mathrm{~K}$ isotope in a highly sensitive $3 P$ whole-body counter with a CV of $2.2 \%(19,20)$. Total body water (TBW) was determined by the isotope dilution of tritiated water (THO) (CV, 3.2\%), as described previously (19). Tritiated water dilution may overestimate the TBW compartment because of the exchange of the isotope label with non-aqueous hydroxyl and carboxyl groups of fatty acids, carbohydrates and proteins (21). A 5\% correction for hydrogen isotope exchange was therefore applied to the THO measurements (22).

Total body nitrogen (TBN) was measured by in vivo neutron activation from a ${ }^{252} \mathrm{Cf}$ source (accuracy of $\pm 4 \%$ ), as described previously $(15,23,24)$.

Dual-energy X-ray absorptiometry (DXA) (Lunar DPX-L; Lunar Corporation, Madison, WI, USA) was used to measure total body bone mineral content, lean body mass (LBMDXA) and BFDXA, as described previously $(15,25)$. The precision errors (1 S.D.) of the scanner that was used were determined from double examinations of 10 healthy subjects and were $1.7 \%$ for BF and $0.7 \%$ for LBMDXA. 
Bioelectrical impedance analysis (BIA) was used to determine TBWBIA, FFMBIA and BFBIA from equations supplied by the manufacturer, based on comparisons with densitometry in a normal population. With the subject in the supine position, BIA was measured with a frequency of $50 \mathrm{kHz}$ and the BIA101 device (RJL System, Detroit, MI, USA), according to the instructions of the manufacturer. From the BIA measurements, BF, TBW and FFMBIA were also calculated with four regression equations described in previous studies by Kushner et al. (21), Lukaski and Bolonchuk (26), van Loan and Mayclin (27), and Deurenberg et al. (28), with resistance and reactance from BIA as input variables. The BIA resistance measurements had a day-to-day CV of $1.7 \%$ (29).

TBW, body cell mass (BCM), LBMDXA, BF and FFMBIA are presented as a percentage of body weight and designated $\mathrm{TBW} \%, \mathrm{BCM} \%$, $\mathrm{LBMDXA} \% \mathrm{BF} \%$ and FFMBIA\% respectively, with the subscripts 4c, BIA, DXA or THO, when appropriate.

\section{Four- and five-compartment models of body composition}

In the four-compartment model (4c) used for body composition, body weight is the sum of BCM, extracellular water (ECW), fat-free extracellular solids (FFECS) and BF4c. In this model, the input variables are TBK measured in a whole-body counter, TBW derived from THO (TBWTHO), body weight and the normal body weight in a population, as described previously (19). Normative values for the four-compartment model were derived from regression equations from body composition studies of 476 healthy individuals (134 men, 342 women; aged 20-70 years) (19).

Finally, body composition was calculated in a fivecompartment chemical model $(5 \mathrm{c})(15,30)$. In this model, FFM is divided into total body protein (TBN×6.25) and TBWTHO. Total body mineral is estimated as bone mineral content from DXA plus soft tissue mineral derived from the assumption that the soft tissue mineral to bone ash ratio is constant at 0.235 . Total body glycogen was calculated from total body protein, assuming that the ratio of glycogen to protein is constant at 0.044 . BF was then calculated as body weight minus fat-free mass, and was denoted as BF $5 \mathrm{c}$. TBN was measured in 22 of the women and 22 of the men. Men and women with an available TBN measurement did not differ from the group with no TBN measurement in terms of age at the time of diagnosis, duration of disease, age at the start of treatment and peak GH level during insulin-induced hypoglycaemia.

\section{Ethics}

Written, informed consent was obtained from all the patients prior to the study. The ethics committee at the University of Göteborg approved the study.

\section{Statistical methods}

Descriptive statistical results are presented as the mean \pm standard error of the mean (S.E.M.) or $\pm 95 \%$ confidence interval (mean value $\pm 1.96 \times$ S.E.M.) or $95 \%$ limits of agreement (mean value $\pm 1.96 \times$ S.D.) when appropriate. The within-group treatment effects were presented as the mean and the $95 \%$ confidence interval for the individual difference between 6 months and baseline. Between-group (gender) differences at baseline or after 6 months were tested by paired $t$-test. Differences in treatment effects between men and women were analysed by two-way repeated measures ANOVA. Since the groups were matched, McNemar's test was used for binary (categorical) variables. Significance was obtained if the two-tailed probability value was <0.05. Correlation analyses were performed with Fisher's $r$ to $\mathrm{z}$ transformation. The assessment of agreement between two methods was performed with the Bland and Altman plot $(31,32)$.

All the calculations were made with the StatView 4.5 program (Abacus Concepts, Beverley, CA, USA).

\section{Results}

The men and women did not differ in terms of estimated age at the time of diagnosis $(42.9 \pm 2.4$ vs $39.7 \pm 2.6$ years, $P=0.37$ ), duration of hypopituitarism ( $7.0 \pm 1.2$ vs $9.7 \pm 1.3$ years, $P=0.13)$, age at the start of GH treatment $(48.9 \pm 2.3$ and $48.6 \pm 2.1$ years, $P=0.94$ ), peak $\mathrm{GH}$ in response to hypoglycaemia $(0.39 \pm 0.12$ vs $0.33 \pm 0.09 \mathrm{mg} / \mathrm{l}, P=0.69)$, hypothalamic-pituitary disorder or degree of pituitary deficiency (Table 1).

Side effects related to fluid retention occurred in 19 $(43 \%)$ men and $22(50 \%)$ women $(P=0.61)$. They were mild and were most frequently reported during months 1 and 3 of treatment. They resulted in a reduction in the daily dose of $\mathrm{GH}$ in four $(9 \%)$ men and eight $(18 \%)$ women $(P=0.39)$. All side effects resolved in response to the dose reduction.

An average reduction of $1.2 \mathrm{~kg}$ body weight occurred in the women, resulting in a significant reduction in BMI $(P=0.0028)$ with no change in the men. However, the between-group gender difference was not significant (Table 2).

\section{GH dose and serum IGF-I (Table 2)}

After 6 months of treatment, the average daily dose of $\mathrm{GH}$ was similar in men and women, whereas the daily dose of $\mathrm{GH}$ per kg body weight was greater in women than in men (Table 2). At baseline and after 6 months, men displayed higher serum IGF-I concentration and IGF-I SDS than women. The increases in dose and in serum IGF-I concentration between baseline and 6 months were, however, similar, whereas the increase in IGF SDS was greater in men. 
Table 2 BMI, body weight, doses of GH and serum- IGF-I concentration in 44 men and 44 women with GHD at baseline and after 6 months of GH-replacement therapy.

\begin{tabular}{|c|c|c|c|c|}
\hline Variable & $\begin{array}{l}\text { Baseline mean } \\
\text { (S.E.M.)\# }\end{array}$ & $\begin{array}{l}\text { 6-month mean } \\
\text { (S.E.M.)\# }\end{array}$ & $\begin{array}{c}\text { Mean change } \\
\text { (95\% confidence interval) }\end{array}$ & $\begin{array}{c}\text { Between-group } \\
P \text { values } \#\end{array}$ \\
\hline \multicolumn{5}{|c|}{$\mathrm{BMI}\left(\mathrm{kg} / \mathrm{m}^{2}\right)$} \\
\hline Men & $27.48(0.72)$ & $27.40(0.70)$ & $-0.08(-0.33$ to 0.18$)$ & \multirow[t]{2}{*}{0.071} \\
\hline Women & $27.63(0.77)$ & $27.14(0.77)$ & $-0.50(-0.80$ to -0.19$)$ & \\
\hline \multicolumn{5}{|l|}{ BW (kg) } \\
\hline Men & $86.33(2.65)^{\star * *}$ & $86.18(2.62)^{\star \star \star}$ & $-0.15(-1.00$ to 0.70$)$ & \multirow{2}{*}{0.13} \\
\hline Women & 73.47 (1.94) & $72.28(1.95)$ & $-1.19(-2.02$ to -0.35$)$ & \\
\hline \multicolumn{5}{|c|}{ Dose of GH (mg/day) } \\
\hline Men & $0.208(0.011)$ & $0.344(0.017)$ & $0.136(0.097$ to 0.175$)$ & \multirow[t]{2}{*}{0.19} \\
\hline Women & $0.198(0.011)$ & $0.367(0.019)$ & $0.169(0.127$ to 0.211$)$ & \\
\hline \multicolumn{5}{|c|}{ Dose of GH/BW ( $\mu \mathrm{g} / \mathrm{kg} /$ day) } \\
\hline Men & $2.50(0.16)$ & $4.17(0.26)^{\star \star}$ & 1.67 (1.14 to 2.20$)$ & \multirow[t]{2}{*}{0.030} \\
\hline Women & $2.82(0.20)$ & $5.23(0.32)$ & 2.42 (1.81 to 3.02$)$ & \\
\hline \multicolumn{5}{|c|}{ Serum-IGF-I SDS } \\
\hline Men & $-1.03(0.22)$ & $2.01(0.32)^{\star *}$ & 3.12 (2.60 to 3.63$)$ & \multirow[t]{2}{*}{0.036} \\
\hline Women & $-1.95(0.21)$ & $0.57(0.30)$ & 2.44 (1.95 to 2.93$)$ & \\
\hline \multicolumn{5}{|c|}{ Serum-IGF-I ( $\mu \mathrm{g} / \mathrm{l})$} \\
\hline Men & $141.1(12.1)^{\star \star}$ & $287.1(17.0)^{\star \star \star}$ & $149.6(124.9$ to 174.4$)$ & \multirow[t]{2}{*}{0.23} \\
\hline Women & $89.4(8.6)$ & $225.1(17.2)$ & $133.6(106.8$ to 160.4$)$ & \\
\hline
\end{tabular}

${ }^{\star \star} P<0.005 ;{ }^{* \star \star} P<0.05$ (between gender comparison at baseline and after 6 months). \#Between gender treatment effect (paired $t$-tests). BW: body weight.

The required mean dose of GH to elevate IGF-1 SDS by one unit was calculated in men and women. In men, $0.13 \pm 0.01 \mathrm{mg} /$ day elevated IGF-1 SDS by one unit while women needed $0.21 \pm 0.02 \mathrm{mg} /$ day $(P=0.001)$.

At 6 months, an inverse correlation was found between the daily dose of $\mathrm{GH}$ and age in women $(r=-0.4 ; P<0.001)$, but not in men $(r=0.005)$.

\section{Body composition}

Men and women increased their TBW\%, LBMDXA\%, FFMBIA \% and BCM\%, but not ECW\%. Only women displayed a significant increase in TBN\% and a significant reduction in BFDXA\% (Table 3). No significant differences in treatment effects were noted between men and women in any of the measured variables (Table 3).

\section{Body composition determined with different methods}

$\mathrm{BF} \%$ determined at baseline with the four- and fivecompartment models, BIA and DXA displayed different results, DXA giving the highest values and the $4 \mathrm{c}$ model giving the lowest values in both women and men (Table 3).

The changes in $\mathrm{BF} \%(\Delta \mathrm{BF} \%)$ were, however, more similar in women $(P=0.39)$ and men $(P=0.080)$ (ANOVA between methods). When the changes in men were compared with those of women, none of the methods showed significant gender difference (Table 3).

In the Bland-Altman model, differences between two body composition techniques are plotted against the averages of two techniques. The horizontal broken lines in Fig. 1A-C represent the limits of agreement calculated as \pm 1.96 times the S.D. of the differences between the two measurements $[(\Delta \mathrm{BFmethod} 2+$ $\Delta$ BFmethod1)/2]. When the limit of agreement is close to zero, the two methods may be used interchangeably.

The $r$ values and the slope in the Bland-Altman plots reveal that the difference between the two methods estimating changes in $\mathrm{BF}$ depends on the differences in the amount of BF obtained by the two methods. This weakness in the methods seems to occur in a similar magnitude in both men and women.

Although correlation analysis is not the best method to compare two techniques measuring the same variable, significant correlations were found between all methods used for the measurement of changes in $\mathrm{BF}$ in women (Table 4). The same correlations in men were less coherent, with only BIA correlating to DXA and the four-compartment model. The exception is the four- and five-compartment models demonstrating similar strength of correlations in men and women.

The best agreement in change in $\mathrm{BF}$ was found between the four- and five-compartment models (Table 5). Significant differences in the assessment of changes in BF were found between DXA and BIA and DXA and the five-compartment model in men and women, and between BIA and the five-compartment in women only. Methodological differences in assessing changes in BF between men and women were seen for DXA versus BIA, and a similar tendency for BIA versus the five-compartment model and DXA versus the four-compartment model. The largest mean difference in men was between changes in BF measured using DXA and the four-compartment model, and in women between BIA and the five-compartment model (Table 5). 
Table 3 Body composition at baseline and after 6 months of GH-replacement therapy in 44 men and 44 women.

\begin{tabular}{|c|c|c|c|c|}
\hline Variable & Baseline & 6 months & $\begin{array}{c}\text { Mean change } \\
\text { (95\% confidence interval) }\end{array}$ & $\begin{array}{l}\text { Between-group values } \\
\text { (95\% confidence interval) }\end{array}$ \\
\hline \multicolumn{5}{|c|}{ TBW $_{\text {THO }}(\%)$} \\
\hline $\mathrm{M}$ & $53.62(0.56)$ & $55.61(0.74)^{\star \star \star}$ & 1.99 (0.79 to 3.20$)$ & \multirow[t]{2}{*}{$0.54(-1.15$ to 2.24$)$} \\
\hline W & $46.32(0.65)$ & $47.77(0.72)^{*}$ & $1.45(0.18$ to 2.72$)$ & \\
\hline \multicolumn{5}{|c|}{ TBW $_{\text {BIA }}(\%)$} \\
\hline M & $55.46(0.65)$ & $57.10(0.65)^{\star \star *}$ & 1.65 (1.09 to 2.21$)$ & \multirow[t]{2}{*}{$0.13(-0.67$ to 0.93$)$} \\
\hline W & $46.82(0.59)$ & $48.34(0.73)^{\star \star \star}$ & $1.52(0.92$ to 2.11$)$ & \\
\hline \multicolumn{5}{|c|}{$\mathrm{ECW}_{4 \mathrm{c}}(\%)$} \\
\hline $\mathrm{M}$ & $24.66(0.44)$ & $25.29(0.48)$ & $0.63(-0.62$ to 1.88$)$ & \multirow[t]{2}{*}{$0.62(-1.12$ to 2.35$)$} \\
\hline W & $23.10(0.54)$ & $23.11(0.51)$ & $0.02(-1.22$ to 1.25$)$ & \\
\hline \multicolumn{5}{|c|}{ LBM $_{\text {DXA }}(\%)$} \\
\hline $\mathrm{M}$ & $67.23(0.84)$ & $68.82(0.89)^{\star \star}$ & 1.59 (0.60 to 2.57$)$ & \multirow{2}{*}{$-0.78(-1.99$ to 0.42$)$} \\
\hline W & $54.67(0.76)$ & $56.98(0.96)^{\star \star \star}$ & 2.30 (1.36 to 3.25$)$ & \\
\hline \multicolumn{5}{|c|}{$\mathrm{FFM}_{\mathrm{BIA}}(\%)$} \\
\hline $\mathrm{M}$ & $77.09(0.76)$ & $79.54(0.72)^{\star \star \star}$ & 2.45 (1.61 to 3.29$)$ & \multirow[t]{2}{*}{$0.89(-0.13$ to 1.91$)$} \\
\hline W & $65.92(0.59)$ & $67.48(0.71)^{\star \star \star}$ & 1.56 (0.97 to 2.15$)$ & \\
\hline \multicolumn{5}{|c|}{$\mathrm{BCM}_{4 \mathrm{c}}(\%)$} \\
\hline M & $38.62(0.57)$ & $40.43(0.60)^{\star \star \star}$ & $1.82(1.25$ to 2.40$)$ & \multirow[t]{2}{*}{$-0.10(-0.96$ to 0.76$)$} \\
\hline W & $30.96(0.42)$ & $32.87(0.43)^{\star \star \star}$ & 1.92 (1.24 to 2.59$)$ & \\
\hline \multicolumn{5}{|l|}{ TBN (\%) } \\
\hline $\mathrm{M}$ & $2.346(0.057)$ & $2.416(0.077)$ & $0.069(-0.011$ to 0.149$)$ & \multirow[t]{2}{*}{$-0.045(-0.11$ to 0.02$)$} \\
\hline W & $1.882(0.050)$ & $1.995(0.058)^{\star *}$ & $0.114(0.055$ to 0.173$)$ & \\
\hline \multicolumn{5}{|c|}{$\mathrm{BF}_{\mathrm{DEXA}}(\%)$} \\
\hline$M$ & $28.35(0.91)$ & $27.31(0.88)$ & $-1.04(-2.16$ to 0.08$)$ & \multirow[t]{2}{*}{$1.17(-0.22$ to 2.57$)$} \\
\hline W & $41.38(0.86)$ & $39.17(1.07)^{\star \star \star}$ & $-2.21(-3.18$ to -1.25$)$ & \\
\hline \multicolumn{5}{|l|}{$\mathrm{BF}_{4 \mathrm{c}}(\%)$} \\
\hline$M$ & $22.83(0.87)$ & $20.24(1.07)^{\star \star \star}$ & $-2.59(-3.88$ to -1.31$)$ & \multirow[t]{2}{*}{$-0.36(-2.18$ to 1.46$)$} \\
\hline W & $32.68(0.94)$ & $30.45(1.06)^{\star \star}$ & $-2.23(-3.66$ to -0.81$)$ & \\
\hline \multicolumn{5}{|l|}{$\mathrm{BF}_{5 \mathrm{c}}(\%)$} \\
\hline $\mathrm{M}$ & $23.52(1.32)$ & $20.45(1.58)^{\star}$ & $-3.07(-5.41$ to -0.73$)$ & \multirow[t]{2}{*}{$0.50(-1.89$ to 2.89$)$} \\
\hline W & $36.82(1.19)$ & $33.24(1.48)^{\star *}$ & $-3.57(-5.69$ to -1.46$)$ & \\
\hline \multicolumn{5}{|l|}{$\mathrm{BF}_{\mathrm{BIA}}(\%)$} \\
\hline $\mathrm{M}$ & $22.91(0.77)$ & $20.69(0.70)^{\star \star \star \star}$ & $-2.22(-3.06$ to -1.37$)$ & \multirow[t]{2}{*}{$-0.71(-1.73$ to 0.30$)$} \\
\hline W & $34.72(0.57)$ & $33.21(0.72)^{\star \star \star}$ & $-1.51(-2.14$ to -0.87$)$ & \\
\hline
\end{tabular}

${ }^{\star} P<0.05 ;{ }^{* \star} P<0.01 ;{ }^{* \star *} P<0.001$ (within-group comparisons baseline to 6 months).

\section{Bioelectric impedance assays}

The changes in BF obtained from different BIA equations produced different results in both men and women (ANOVA, $P<0.001$ ). The decrease in BF was smallest with the van Loan equation in men, while the Deurenberg and Lukaski equations demonstrated the most marked BF reduction in both men and women. The changes in BF obtained with the various equations correlated with each other. The lowest $r$ values were 0.53 and 0.85 for men and women respectively. None of the BIA equations revealed significant gender differences in the treatment response with respect to BF (data not shown).

\section{Subgroup analysis}

Women were subdivided with respect to the route of oestrogen administration. At baseline, women without oestrogen replacement therapy were about 10 years older than women with treatment. They had also lower BMI and $\mathrm{BF} 4 \mathrm{c} \%$ than women with transdermal oestrogen therapy. No further differences were noted, and there were no significant differences in response to $\mathrm{GH}$ replacement between the groups.
The same subgroups of women were then compared with the men in a paired analysis. Men and women had similar mean ages and BMI, while BW and BCM\% was higher in men in all groups. The doses of $\mathrm{GH}$ and the increase in IGF-I SDS did not differ between men and women in either pair of groups.

\section{Discussion}

Responsiveness to $\mathrm{GH}$ replacement was studied in men and women with GHD who were closely matched in terms of age, BMI and degree of anterior pituitary hormone deficiency. Dose titration resulted in a similar daily dose of GH and mean serum IGF-I increase in men and women, allowing study of gender difference not explained by background factors. Moreover, with several techniques and models to measure body composition, their use for men and women during GH replacement could be compared.

When we compared the four- and five-compartment models by the use of ${ }^{40} \mathrm{~K}$, tritiated water and TBN from in vitro neutron activation, the mean difference in change in BF was nearly zero, and the $95 \%$ limits of 

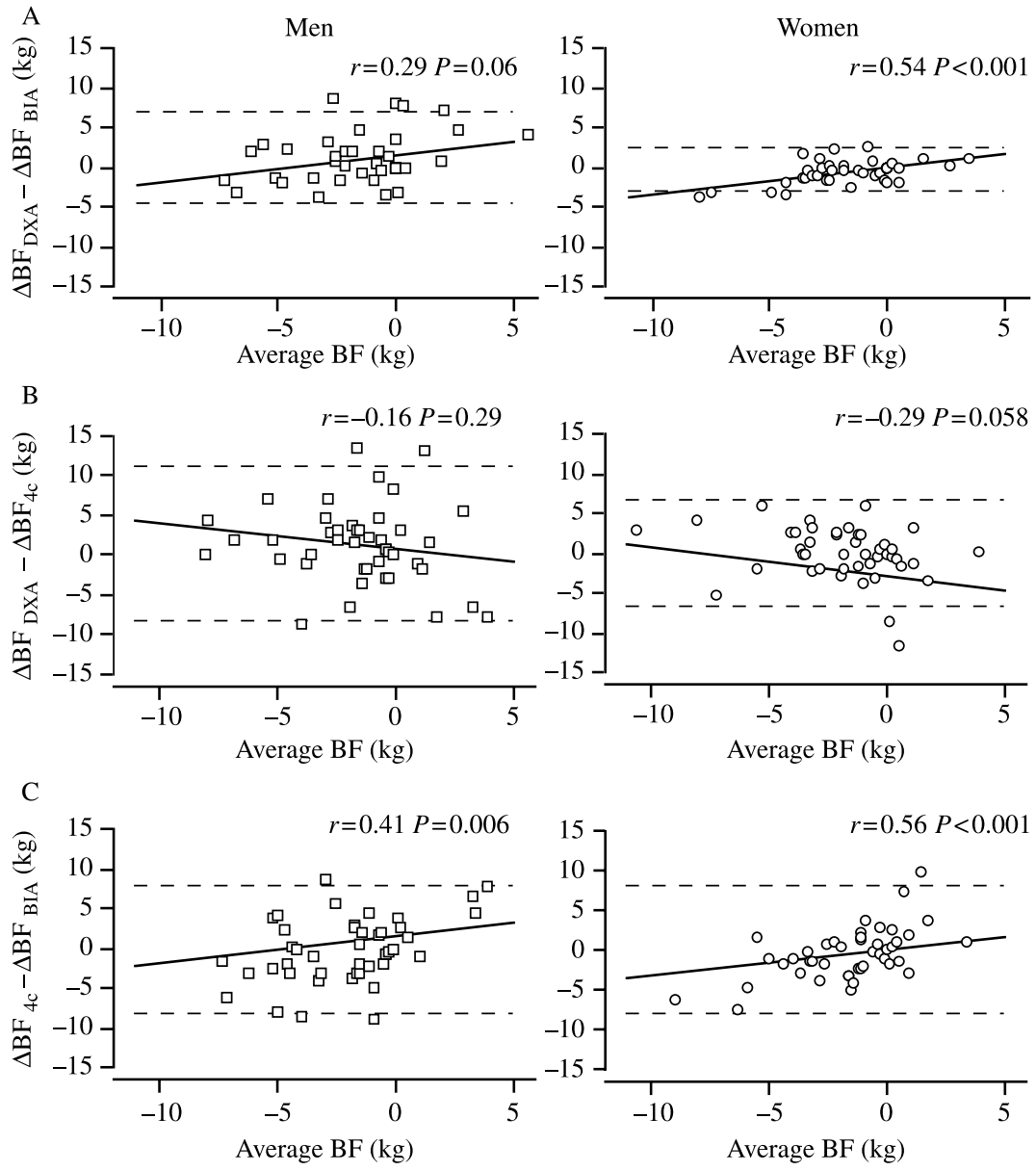

Figure 1 Method of comparison showing the agreement in changes in $B F(\mathrm{~kg})$ after 6 months of $\mathrm{GH}$ treatment with DXA, BIA and the four-compartment model. In this model, the differences between the changes obtained by the two methods are plotted against the mean with $95 \%$ limit of agreement (broken line) and regression line (Bland-Altman plot). agreement between these two methods were narrower than those between any other two methods in response to $\mathrm{GH}$ treatment in both men and women (Fig. 1 and Table 5). These two methods may therefore be used interchangeably, especially when studying gender differences.

Due to the strong association between TBW and $\mathrm{LBM}$, there is a good correlation between resistance obtained from BIA and FFMBIA. However, BIA mainly measures electrical conductivity in the extremities (33). In individuals with predominantly central fat distribution, such as adults with GHD, BIA may underestimate $\mathrm{BF}$ mass and the change in $\mathrm{BF}$ during $\mathrm{GH}$ treatment, which primarily affects central fat depots $(14,34)$. An essential assumption in BIA measurements is a sustained, well-defined hydration and electrolyte level in LBM. Since GHD is known to be associated with alterations in TBW and fluid distribution, the relationship between impedance and percentage of $\mathrm{BF}$ is likely to be different than that observed in healthy, normal subjects. Therefore, in addition to the relative insensitivity to changes in body composition in the abdomen, BIA also overestimates BF in dehydrated subjects, as shown by studies comparing results from BIA with methods less dependent on hydration and electrolyte levels, such as skin-fold measurement (35) and whole-body magnetic resonance imaging (36). Moreover, the estimation error of TBW and ECW was found to depend on the magnitude of TBW when BIA was compared with a multicompartment model (37). Finally, the discrepancy in BF obtained with different BIA equations may also reflect the fact that none of these were developed in adults with GHD. All these factors may influence the success with which BIA reflects the absolute values and alterations of BF after $\mathrm{GH}$ replacement in men and women. Therefore, where marked changes in hydration level and electrolyte levels are expected, BIA may be less well suited to measure changes in body composition. In this study, BIA tended to show larger changes in FFM and BF in response to $\mathrm{GH}$ treatment in men than women (Table 3).

DXA creates a digital two-dimensional image of the body with two X-ray energies. The image is then analysed and transformed to tissue, depending on the attenuation of the X-rays. As a result, areas that do not include bone can be separated into fat and lean tissue. In areas consisting of bone and soft tissue, an 
Table 4 Correlations between changes in total body fat $(\mathrm{kg})$ measured using BIA, DXA, four and five compartment model.

\begin{tabular}{|c|c|c|c|c|}
\hline & \multicolumn{2}{|c|}{ Men } & \multicolumn{2}{|c|}{ Women } \\
\hline & $r$ value & $P$ value & $r$ value & $P$ value \\
\hline$\Delta \mathrm{BF}_{\mathrm{DXA}}$ vs $\Delta \mathrm{BF}_{\mathrm{BIA}}$ & 0.51 & $<0.001$ & 0.87 & $<0.001$ \\
\hline$\Delta \mathrm{BF}_{\mathrm{DXA}}$ vs $\Delta \mathrm{BF}_{4 \mathrm{c}}$ & 0.082 & 0.60 & 0.44 & 0.002 \\
\hline$\Delta \mathrm{BF}_{\mathrm{DXA}}$ vs $\Delta \mathrm{BF}_{5 \mathrm{c}}$ & 0.10 & 0.65 & 0.67 & $<0.001$ \\
\hline$\Delta \mathrm{BF}_{\mathrm{BIA}}$ vs $\Delta \mathrm{BF}_{4 \mathrm{c}}$ & 0.26 & 0.090 & 0.56 & 0.002 \\
\hline$\Delta \mathrm{BF}_{\mathrm{BIA}}$ vs $\Delta \mathrm{BF}_{5 \mathrm{c}}$ & 0.46 & 0.028 & 0.65 & $<0.001$ \\
\hline$\Delta \mathrm{BF}_{4 \mathrm{c}}$ vs $\Delta \mathrm{BF}_{5 \mathrm{c}}$ & 0.98 & $<0.001$ & 0.98 & $<0.001$ \\
\hline
\end{tabular}

extrapolation of the composition of tissue has to be made from adjacent areas not containing bone. The main weaknesses of this method are that the travel distance of the rays through the body at any given point is not known, and the tissue is assumed to be homogeneous. In areas where several different tissues overlap, the result is less accurate, especially in areas dominated by bone, such as the abdomen. This may explain the poor correlation found in DXA compared with the four-compartment model, which does not share this weakness with DXA. Since both DXA and BIA share the common weakness of poor precision with respect to the abdominal region, it is tempting to suggest that DXA and BIA may be less well suited to follow changes in body composition in men, as suggested by the poor correlation between different body composition methods that we found in men (Table 4). A previous study showed that DXA underestimated BF mass in subjects with a large waist circumference (38), thereby tending to support our finding that the largest difference between men and women in terms of changes in BF $(1.17 \%)$ is in the DXA measurements.
The changes in BF correlated less well between various methods in men than in women. The discrepancy between the DXA and BIA in men was most striking, the $95 \%$ limits of agreement between the two methods being much wider in men than women (Fig. 1), meaning that one of these methods may give less reliable results than the other in men. There was a tendency for better consistency among the body composition methods in measuring changes in BF in women, except that BIA showed virtually the same limits of agreement in both men and women. This indicates that BIA detects changes in BF in a similar manner in men and women (Fig. 1). The correlation analysis points in the same direction showing smaller absolute $r$ values in men, particularly when the four- and fivecompartment methods were compared with DXA and BIA. This is to be expected since the CV for BIA and DXA is smaller than for the four- and five-compartment methods (Table 4). The discrepancy between the models of assessment in men and women is probably due to the different baseline and the different distribution of lean and fat tissue in men and women (39-41).

The multicompartment models based on measurements of TBK and TBW may better reflect the whole body and be less dependent on the distribution of lean and fat mass. The marked change in body hydration might affect the validity of using BIA and DXA, as they have been shown to underestimate BF in dehydrated subjects $(42,43)$. Although the magnitude of these errors is not considered to be of major significance in clinical research $(44,45)$, they can be reduced by using a more direct measurement of TBW and ECW.

Women with GHD have a lower serum IGF-I SDS than men, in spite of similar GH responses to the ITT test and GH secretory status (18), which might be explained by oral oestrogen treatment (6) and/or a

Table 5 Method comparison showing 95\% limits of agreement between DXA, BIA and the four and five-compartment models measuring changes in $\mathrm{BF}(\Delta \mathrm{BF})$ after 6 months of $\mathrm{GH}$ treatment.

\begin{tabular}{|c|c|c|c|c|}
\hline & Mean $(\mathrm{kg})$ & $95 \%$ limits of agreement\# & Within-group $\boldsymbol{P}$ value\#\# & Between-group $\boldsymbol{P}$ value\#\# \\
\hline \multicolumn{5}{|c|}{$\Delta \mathrm{BF}_{\mathrm{DXA}}-\Delta \mathrm{BF}_{\mathrm{BIA}}$} \\
\hline Men & 1.10 & -4.75 to 6.96 & 0.018 & \multirow[t]{2}{*}{0.025} \\
\hline Women & -0.52 & -3.27 to 2.23 & 0.019 & \\
\hline \multicolumn{5}{|c|}{$\Delta \mathrm{BF}_{\mathrm{DXA}}-\Delta \mathrm{BF}_{4 \mathrm{c}}$} \\
\hline Men & 1.30 & -8.34 to 10.95 & 0.087 & \multirow[t]{2}{*}{0.20} \\
\hline Women & -0.03 & -6.68 to 6.63 & 0.96 & \\
\hline \multicolumn{5}{|c|}{$\Delta \mathrm{BF}_{\mathrm{DXA}}-\Delta \mathrm{BF}_{5 \mathrm{c}}$} \\
\hline Men & 0.94 & -9.92 to 11.79 & $<0.001$ & \multirow[t]{2}{*}{0.99} \\
\hline Women & 0.56 & -5.24 to 6.37 & $<0.001$ & \\
\hline \multicolumn{5}{|c|}{$\Delta \mathrm{BF}_{\mathrm{BIA}}-\Delta \mathrm{BF}_{4 \mathrm{c}}$} \\
\hline Men & 0.20 & -7.83 to 8.22 & 0.75 & \multirow[t]{2}{*}{0.73} \\
\hline Women & 0.49 & -5.80 to 6.79 & 0.31 & \\
\hline \multicolumn{5}{|c|}{$\Delta \mathrm{BF}_{\mathrm{BIA}}-\Delta \mathrm{BF}_{5 \mathrm{c}}$} \\
\hline Men & 0.24 & -8.24 to 8.72 & 0.80 & \multirow[t]{2}{*}{0.06} \\
\hline Women & 1.44 & -4.36 to 7.24 & 0.033 & \\
\hline \multicolumn{5}{|c|}{$\Delta \mathrm{BF}_{4 \mathrm{c}}-\Delta \mathrm{BF}_{5 \mathrm{c}}$} \\
\hline Men & -0.05 & -1.99 to 1.90 & 0.82 & \multirow[t]{2}{*}{0.83} \\
\hline Women & -0.01 & -1.37 to 1.34 & 0.93 & \\
\hline
\end{tabular}

\# $1.96 \times$ S.D.; \#\#paired tests. 
lower lean body mass (18). In men and women with GHD, dose titration according to serum IGF-I levels gave women a slightly higher total dose of $\mathrm{GH}$, but men and women experienced the same reduction in central adiposity in response to treatment (17), suggesting that women are less responsive to the same total dose of $\mathrm{GH}(3,5,46)$.

In this study, dose titration resulted in similar total daily doses of $\mathrm{GH}$ and produced similar increments in IGF-I in men and women. The dose of $\mathrm{GH}$ per $\mathrm{kg}$ body weight and the calculated dose of $\mathrm{GH}$ needed to produce an increase of one IGF-I SDS was, however, larger in women than in men. Therefore, women did respond less markedly to $\mathrm{GH}$ in terms of the serum IGF-I response (hepatic response), but when adjustments were made for age and BMI, the changes in body composition and serum IGF-I were more alike. Moreover, the previously described differences in GHinduced changes in body composition in men and women may even be smaller if methods least dependent on gender are used.

A weakness of this trial was the varying oestrogen status of the women, who were taking oral, transdermal or no oestrogen. We were unable to detect differences between these groups in terms of the response to $\mathrm{GH}$ treatment and in the comparison with matched men, indicating a minor impact on the results of this trial.

The previously described differences in responsiveness to GH replacement therapy in men and women are attenuated when age and BMI, together with individualized GH dose titration, are adjusted for. For clinical purposes, changes in body composition during $\mathrm{GH}$ replacement are well described by all the methods used in this trial. However, the results obtained in this analysis suggest that a multicompartment model is most appropriate for the assessment and comparison of body composition in men and women during $\mathrm{GH}$ treatment.

\section{Acknowledgements}

This work was supported by grants from the Swedish Medical Research Council (project no. 11621). We thank Lena Wirén, Anne Rosén, Ingrid Hansson, Annika Reibring and Anna Olsson, at the Research Center for Endocrinology and Metabolism, for skilful technical support.

\section{References}

1 Johansson A. Gender difference in growth hormone response in adults. Journal of Endocrinological Investigation 199922 (Suppl 5) 58-60.

2 Verhelst J, Abs R, Vandeweghe M, Mockel J, Legros JJ, Copinschi G, Mahler C, Velkeniers B, Vanhaelst L, Van-Aelst A, De-Rijdt D, Stevenaert A \& Beckers A. Two years of replacement therapy in adults with growth hormone deficiency. Journal of Clinical Endocrinology and Metabolism 199747 485-494.
3 Johannsson G, Bjarnason R, Bramnert M, Carlsson LMS, Degerblad M, Manhem P, Rosén T, Thorén M \& Bengtsson B-Å. The individual responsiveness to growth hormone $(\mathrm{GH})$ treatment in GH-deficient adults is dependent on the level of GH binding protein, body mass index, age and gender. Journal of Clinical Endocrinology and Metabolism 199681 1575-1581.

4 Johannsson G, Grimby G, Stibrant Sunnerhagen K \& Bengtsson B- Å. Two years of growth hormone $(\mathrm{GH})$ treatment increases isometric and isokinetic muscle strength in GH-deficient adults. Journal of Clinical Endocrinology and Metabolism $1997 \mathbf{8 2}$ 2877-2884.

5 Burman P, Johansson AG, Siegbahn A, Vessby B \& Karlsson FA. Growth hormone $(\mathrm{GH})$-deficient men are more responsive to $\mathrm{GH}$ replacement therapy than women. Journal of Clinical Endocrinology and Metabolism 199782 550-555.

6 Weissberger AJ, Ho KY \& Lazarus L. Contrasting effects of oral and transdermal routes of estrogen replacement therapy on 24-hour growth hormone $(\mathrm{GH})$ secretion, insulin-like growth factor I, and GH-binding protein in postmenopausal women. Journal of Clinical Endocrinology and Metabolism 199172 374-381.

7 O'Sullivan AJ, Crampton LJ, Freund J \& Ho KK. The route of estrogen replacement therapy confers divergent effects on substrate oxidation and body composition in postmenopausal women. Journal of Clinical Investigations $1998 \mathbf{1 0 2} 1035-1040$.

8 Leung KC, Doyle N, Ballesteros M, Sjogren K, Watts CK, Low TH, Leong GM, Ross RJ \& Ho KK. Estrogen inhibits GH signaling by suppressing GH-induced JAK2 phosphorylation, an effect mediated by SOCS-2. PNAS 2003100 1016-1021.

9 Katznelson L, Finkelstein JS, Schoenfeld DA, Rosenthal DI, Anderson EJ \& Klibanski A. Increase in bone density and lean body mass during testosterone administration in men with acquired hypogonadism. Journal of Clinical Endocrinology and Metabolism $1996 \mathbf{8 1} 4358-4365$.

10 Gibney J, Wolthers T, Johannsson G, Umpleby A \& Ho K. Growth hormone and testosterone interact positively to enhance protein and energy metabolism in hypopituitary men. American Journal of Physiology and Endocrinological Metabolism 2005289 E2 66-E271.

11 Ho KY, Evans WS, Blizzard RM, Veldhuis JD, Merriam GR, Samojlik E, Furlanetto R, Rogol AD, Kaiser DL \& Thorner MO. Effects of sex and age on the 24-hour profile of growth hormone secretion in man. Importance of endogenous estradiol concentrations. Journal of Clinical Endocrinology and Metabolism 1987 $6451-58$.

12 Van den Berg G, Veldhuis JD, Frölich M \& Roelfsema F. An amplitude-specific divergence in the pulsatile mode of $\mathrm{GH}$ secretion underlies the gender difference in mean $\mathrm{GH}$ concentration in men and premenopausal women. Journal of Clinical Endocrinology and Metabolism $1996 \mathbf{8 1} 2460-2467$.

13 Salomon F, Cuneo RC, Hesp R \& Sönksen PH. The effects of treatment with recombinant human growth hormone on body composition and metabolism in adults with growth hormone deficiency. New England Journal of Medicine 1989321 1797-1803.

14 Bengtsson B-Å, Edén S, Lönn L, Kvist H, Stokland A, Lindstedt G, Bosaeus I, Tölli J, Sjöström L \& Isaksson OGP. Treatment of adults with growth hormone $(\mathrm{GH})$ deficiency with recombinant human GH. Journal of Clinical Endocrinology and Metabolism $1993 \mathbf{7 6}$ 309-317.

15 Bosaeus I, Johannsson G, Rosén T, Hallgren P, Tölli J, Sjöström L \& Bengtsson B-Å. Comparison of methods to estimate body fat in growth hormone deficient adults. Clinical Endocrinology 1996 44 395-402.

16 Johannsson G, Rosén T \& Bengtsson B-Å. Individualized dose titration of growth hormone $(\mathrm{GH})$ during $\mathrm{GH}$ replacement in hypopituitary adults. Clinical Endocrinology 199747 571-581.

17 Drake W, Coyte D, Camacho-Hubner C, Jivanji N, Kaltsas G, Wood DF, Trainer P, Grossman A, Besser G \& Monson J. Optimizing growth hormone replacement therapy by dose titration in hypopituitary adults. Journal of Clinical Endocrinology and Metabolism 199883 3913-3919. 
18 Svensson J, Johannsson G \& Bengtsson B- $\AA$. Insulin-like growth factor-I in growth hormone-deficient adults: relationship to population-based normal values, body composition and insulin tolerance test. Clinical Endocrinology 199746 579-586.

19 Bruce $\AA$, Andersson M, Arvidsson B \& Isaksson B. Body composition. Prediction of normal body potassium, body water and body fat in adults on the basis of body height, body weight and age. Scandinavian Journal of Clinical Laboratory Investigation 1980 $40461-473$.

20 Skoldborn H, Arvidsson B \& Andersson M. A new whole body monitoring laboratory. Acta Radiologica Supplementum 1972313 $233-241$.

21 Kushner R, Kunigk A, Alspaugh M, Andronis P, Leitch C \& Schoeller D. Validation of bioelectrical-impedance analysis as a measurement of change in body composition in obesity. American Journal of Clinical Nutrition 199052 19-23.

22 Culebras J \& Moore F. Total body water and the exchangeable hydrogen. I. Theoretical calculation of nonaqueous exchangeable hydrogen in men. American Journal of Physiology 1977232 R54-R59.

23 Tolli J, Bengtsson BA, Bosaeus I, Johansson G \& Alpsten M. A comparison of different methods to measure body composition in patients. Applied Radiation and Isotopes $1998 \mathbf{4 9} 469-472$.

24 Ellis K, Yasumura S, Vartsky D, Vaswani A \& Cohn SH. Total body nitrogen in health and disease: effects of age, weight, height and sex. Journal of Laboratory and Clinical Medicine $198299917-926$.

25 Mazess RB, Barden HS, Bisek JP \& Hanson J. Dual-energy X-ray absorptiometry for total-body and regional bone-mineral and soft-tissue composition. American Journal of Clinical Nutrition $1990511106-1112$.

26 Lukaski H \& Bolonchuk W. Theory and validation of the tetrapolar bioelectrical impedance method to assess human body composition. In In vivo body composition studies, pp 410-414. Eds KJ Ellis, S Yasamura \& WD Morgan. London: Institute of Physical Sciences in Medicine 1987.

27 van Loan M \& Mayclin P. Bioelectrical impedance analysis is a reliable estimator of lean body mass and total body water. Human Biology 198759 299-309.

28 Deurenberg P, Weststrate J \& van der Kooky K. Body composition changes assessed by bioelectrical impedance measurements. American Journal of Clinical Nutrition $1989 \mathbf{4 9} 401-403$.

29 Brummer R-JM, Rosén T \& Bengtsson B-A. Evaluation of different methods of determining body composition, with special reference to growth hormone-related disorders. Acta Endocrinologica 1993 128 (Suppl 2) 30-36.

30 Royall D, Greenberg G, Allard J, Baker J, Harrison J \& Jeejeebhoy K. Critical assessment of body composition measurements in malnourished subjects with Crohn's disease: the role of bioelectric impedance analysis. American Journal of Clinical Nutrition 1994 $59325-330$.

31 Bland J \& Altman D. Statistical methods for assessing agreement between two methods of clinical measurement. Lancet 1986327 307-310.

32 Bland J \& Altman D. Comparing methods of measurement: why plotting difference against standard method is misleading. Lancet $19953461085-1087$.

33 Baumgartner RN, Chumlea WC \& Roche AF. Bioelectric impedance phase angle and body composition. American Journal of Clinical Nutrition $1988 \mathbf{4 8} 16-23$.
34 Lönn L, Johannsson G, Sjöström L, Kvist H, Odén A \& Bengtsson B- $\AA$. Body composition and tissue distributions in growth hormone deficient adults before and after growth hormone treatment. Obesity Research 19964 45-54.

35 De Boer H, Blok GJ, Voerman HJ, de Vries PMJ \& van der Veen EA. Body composition in adult growth hormone-deficient men, assessed by anthropodometry and bioimpedance analysis. Journal of Clinical Endocrinology and Metabolism 199275 833-837.

36 Janssen I, Heymsfield S, Baumgartner R \& Ross R. Estimation of skeletal muscle mass by bioelectrical impedance analysis. Journal of Applied Physiology $2000 \mathbf{8 9} 465-471$.

37 Janssen YJH, Deurenberg P \& Roelfsema F. Using dilution techniques and multifrequency bioelectrical impedance to assess both total body water and extracellular water at baseline and during recombinant human growth hormone $(\mathrm{GH})$ treatment in GH-deficient adults. Journal of Clinical Endocrinology and Metabolism 199782 3349-3355.

38 Koda M, Ando F, Nimo N, Tsuzuku S \& Shimokata H. Comparison between the air displacement method and dual energy x-ray absorptiometry for estimation of body fat. Journal of Epidemiology 200010 S82-S89.

39 Heitmann BL. Body fat in the adult Danish population aged 35-65 years: an epidemiological study. International Journal of Obesity 199115 535-545.

40 Janssen I, Heymsfield SB, Wang ZM \& Ross R. Skeletal muscle and distribution in 468 men and women aged 18-88 years. Journal of Applied Physiology $2000 \mathbf{8 9} 81-88$.

41 Gallagher D \& Heymsfield SB. Muscle distribution: variations with body weight, gender, and age. Applied Radiation and Isotopes 1998 $49733-734$.

42 Thompson D, Thompson W, Prestridge T, Bailey J, Bean M, Brown S \& McDaniel J. Effect of hydration and dehydration on body composition analysis: a comparative study of bioelectric impedance analysis and hydrodensitometry. Journal of Sports Medicine and Physical Fitness 199131 565-570.

43 Brodie DA, Eston RG, Coxon AY, Kreitzman SN, Stockdale HR \& Howard AN. Effect of changes of water and electrolytes on the validity of conventional methods of measuring fat-free mass. Annals of Nutrition and Metabolism 35 89-97.

44 Testolin G, Gore R, Rivkin T, Horlick M, Arbo J, Wang Z, Chiumello G \& Heymsfield B. Dual-energy X-ray absorptiometry: analysis of pediatric fat estimate errors due to tissue hydration effects. Journal of Applied Physiology 200089 2365-2372.

45 Ritz P. Body water spaces and cellular hydration during healthy aging. Annals of the New York Academy of Sciences $2000 \mathbf{9 0 4}$ 474-483.

46 Drake W, Rodriguez-Arnao J, Weaver J, James IT, Coyte D, Spector TD, Besser GM \& Monson JP. The influence of gender on the short and long-term effects of growth hormone replacement on bone metabolism and bone mineral density in hypopituitary adults: a 5-year study. Clinical Endocrinology (Oxford) $20015 \mathbf{5 4}$ 525-532.

Received 12 September 2005

Accepted 12 January 2006 